\title{
Early Alveolar Epithelial Cell Necrosis is a Potential Driver of ARDS with
}

\section{COVID-19}

Kentaro Tojo ${ }^{1}$, Natsuhiro Yamamoto ${ }^{1}$, Nao Tamada ${ }^{1,2}$, Takahiro Mihara ${ }^{3}$, Miyo Abe ${ }^{1}$, Takahisa Goto $^{1}$

\section{Author Affiliations:}

${ }^{1}$ Department of Anesthesiology and Critical Care Medicine, Yokohama City University

School of Medicine, Yokohama, Kanagawa, Japan

${ }^{2}$ Department of Paramedic, Kyorin University Faculty of Health Sciences, Mitaka,

Tokyo, Japan

${ }^{3}$ Department of Health Data Science, Yokohama City University Graduate School of

Data Science, Yokohama, Kanagawa, Japan

\section{Corresponding Author:}

Kentaro Tojo, MD, PhD

Department of Anesthesiology and Critical Care Medicine, Yokohama City University

School of Medicine, 3-9, Fukuura, Kanazawa-ku, Yokohama 236-0004, Japan

e-mail: ktojo@yokohama-cu.ac.jp 
medRxiv preprint doi: https://doi.org/10.1101/2022.01.23.22269723; this version posted January 24, 2022. The copyright holder for this preprint (which was not certified by peer review) is the author/funder, who has granted medRxiv a license to display the preprint in It is made available under a CC-BY-NC 4.0 International license.

Fax: +81-45-787-2916; Tel: +81-45-787-2918

\section{The impact of this research}

Alveolar tissue injury in acute respiratory distress syndrome (ARDS) with COVID-19 is aggravated by hyperinflammatory responses even after passing the peak of viral load.

Our analysis of serum samples from COVID-19 patients and an animal model revealed that alveolar epithelial necrosis, including necroptosis and pyroptosis, occurs at the early disease stage of COVID-19-induced ARDS. Moreover, our data indicated that damage-associated molecular patterns released from necrotic alveolar epithelial cells are promising therapeutic targets to prevent the COVID-19 aggravation.

\section{Author Contributions:}

Conceptualization and study design: KT. Acquisition of clinical study data: KT, NY, MA. Acquisition of animal experiments data: KT, NT. Analysis and interpretation of data: KT, NY, NT, TM, TG. Manuscript Writing: KT. Manuscript Editing: All investigators.

\section{Funding and Disclosures:}


medRxiv preprint doi: https://doi.org/10.1101/2022.01.23.22269723; this version posted January 24, 2022. The copyright holder for this preprint (which was not certified by peer review) is the author/funder, who has granted medRxiv a license to display the preprint in It is made available under a CC-BY-NC 4.0 International license

This work was partly supported by AMED under Grant Number JP20he0522001 and JSPS KAKENHI Grant Number 21K16575, and Grant for 2020-2021 Research

Development Fund of Yokohama City University. 


\begin{abstract}
Rationale

Acute respiratory distress syndrome (ARDS) with COVID-19 is aggravated by

hyperinflammatory responses even after passing the peak of viral load. However, the underlying mechanisms remain unclear.
\end{abstract}

\title{
Objectives
}

Here, we assess whether alveolar epithelial cell necrosis and subsequent releases of damage associated molecular patterns (DAMPs) at an early disease stage aggravate ARDS with COVID-19

\section{Methods}

In patients with COVID-19 with and without ARDS and healthy adults, serum levels of the following were quantified: an epithelial total cell death marker, cytokeratin18-M65; an epithelial apoptosis marker, CK18-M30; HMGB-1; and alveolar epithelial and endothelial injury markers, sRAGE, angiopoietin-2, and surfactant protein-D. Molecular mechanisms of alveolar epithelial cell death and effects of HMGB-1 neutralization on alveolar tissue injury were assessed using a mouse model of COVID-19-induced ARDS.

\section{Measurements and main results}


medRxiv preprint doi: https://doi.org/10.1101/2022.01.23.22269723; this version posted January 24, 2022. The copyright holder for this preprint (which was not certified by peer review) is the author/funder, who has granted medRxiv a license to display the preprint in It is made available under a CC-BY-NC 4.0 International license .

The levels of CK18-M65, CK18-M30, and alveolar tissue injury markers were elevated in early stages of ARDS. The median M30/M65 ratio, an epithelial apoptosis indicator, was $31.50 \%$ in patients with ARDS, a value significantly lower than that of non-ARDS patients or healthy subjects. Serum levels of HMGB-1, one of DAMPs released from necrotic cells, were also significantly elevated in ARDS versus non-ARDS patients. In a COVID-19-induced ARDS mouse model, alveolar epithelial cell necrosis involved two forms of programmed necrosis, necroptosis and pyroptosis. Finally, neutralization of HMGB-1 attenuated alveolar tissue injury in the mouse model.

\section{Conclusions}

Necrosis, including necroptosis and pyroptosis, seems to be the primary form of alveolar epithelial cell death, and subsequent release of DAMPs is a potential driver of COVID-19-induced ARDS.

MeSH Terms: SARS-CoV-2; Respiratory Distress Syndrome; Necroptosis; Pyroptosis, HMGB Proteins 
medRxiv preprint doi: https://doi.org/10.1101/2022.01.23.22269723; this version posted January 24,2022 . The copyright holder for this preprint (which was not certified by peer review) is the author/funder, who has granted medRxiv a license to display the preprint in It is made available under a CC-BY-NC 4.0 International license.

\section{Introduction}

Infection with a novel strain of coronavirus, severe acute respiratory syndrome coronavirus 2 (SARS-CoV-2), causes coronavirus disease 2019 (COVID-19)

pneumonia. In the most severe cases, the disease progresses to acute respiratory distress syndrome (ARDS), which is associated with severe alveolar tissue injury $(1,2)$.

Interestingly, the disease severity is exacerbated by hyperinflammatory responses even after passing the peak of viral load(3,4). However, the mechanisms that underly disease aggravation remain unclear. We and others previously reported that alveolar epithelial injury at a very early disease stage is a hallmark of COVID-19-induced $\operatorname{ARDS}(5,6)$, suggesting that alveolar epithelial injury may be a trigger of subsequent disease progression. Therefore, elucidating the detailed mechanisms by which alveolar epithelial injury occurs in COVID-19 may reveal a therapeutic target that prevents disease aggravation.

In ARDS, alveolar epithelial cells undergo cell death(7, 8). Although previous studies have demonstrated that both alveolar epithelial necrosis and apoptosis are important for the pathogenesis of $\operatorname{ARDS}(8)$, a recent study in our lab demonstrated that necrosis is the primary form of alveolar epithelial cell death in lipopolysaccharide (LPS)-induced experimental ARDS(9). Moreover, programmed necrosis have been 
medRxiv preprint doi: https://doi.org/10.1101/2022.01.23.22269723; this version posted January 24, 2022. The copyright holder for this preprint (which was not certified by peer review) is the author/funder, who has granted medRxiv a license to display the preprint in It is made available under a CC-BY-NC 4.0 International license .

shown to be involved in alveolar epithelial cell death in several animal ARDS

models(10-13). In contrast to apoptosis, which does not elicit inflammation, necrosis causes the release of damage-associated molecular patterns (DAMPs) such as high mobility group box (HMGB)-1 from dead cells $(14,15)$. Therefore, it is possible that alveolar necrosis during early disease stages, and the subsequent release of DAMPs, may drive disease progression in COVID-19-associated ARDS(16, 17).

Here, we assess whether alveolar epithelial cell necrosis and subsequent release of DAMPs aggravate COVID-19-associated ARDS. To determine alveolar epithelial cell death patterns in COVID-19 patients with or without ARDS, we analyzed serum levels of full-length (CK18-M65 antigen) and caspase-cleaved (CK18-M30 antigen)

cytokeratin 18, which are epithelial total cell death and epithelial apoptosis markers respectively, in addition to the other several alveolar epithelial and endothelial injury markers. Moreover, we investigated the detailed mechanisms of alveolar epithelial cell death using the animal model mimicking COVID-19-induced ARDS. Finally, we evaluated whether blockade of HMGB-1, one of DAMPs released from necrotic cells, can attenuate alveolar tissue injury in the animal model.

Some of the preliminary results of the study were published previously(5). 
medRxiv preprint doi: https://doi.org/10.1101/2022.01.23.22269723; this version posted January 24, 2022. The copyright holder for this preprint (which was not certified by peer review) is the author/funder, who has granted medRxiv a license to display the preprint in It is made available under a CC-BY-NC 4.0 International license.

\section{Methods}

Detailed methods are provided in online supplementary materials (Text E1).

\section{Clinical study design}

This single-center observational study included adult patients with available serum samples who were admitted to Yokohama City University Hospital with COVID-19 from January 2020 to January 2021. ARDS was diagnosed based on the Berlin definition(18). The study protocol was approved by the Yokohama City University Hospital institutional review board (B200700100). The requirement for informed consent was waived due to the observational nature of the study.

\section{Clinical data collection}

Clinical data were retrospectively collected from each patient's medical chart.

\section{Analysis of human serum samples}

Using enzyme-linked immunosorbent assay (ELISA) kits, serum levels of the following were measured: soluble receptors for advanced glycation end products (sRAGE), angiopoietin (ANG)-2, surfactant protein (SP)-D, CK18-M65, CK18-M30, 
medRxiv preprint doi: https://doi.org/10.1101/2022.01.23.22269723; this version posted January 24, 2022. The copyright holder for this preprint (which was not certified by peer review) is the author/funder, who has granted medRxiv a license to display the preprint in It is made available under a CC-BY-NC 4.0 International license.

and HMGB-1. Concentrations of the above markers at admission (first or second hospital day) of ARDS, non-ARDS, and control individuals were compared. Temporal changes in marker levels in patients with ARDS throughout the first 8 days of admission were assessed.

\section{Animal experiments}

All animal experimental protocols were approved by Yokohama City University Animal Research Committee. Male specific-pathogen-free C57/BL6J mice aged 8-10 weeks were used. Mice were euthanized $24 \mathrm{~h}$ after intratracheal instillation, and tissue and bronchoalveolar lavage fluid (BALF) samples were collected as previously described.

Twelve animals were randomly allocated to one of the following three groups $(\mathrm{n}=$ 4 per group): control, mild COVID-19, and severe COVID-19. The severe COVID-19 group received $50 \mu \mathrm{g}$ SARS-CoV-2 spike protein intratracheally with $250 \mu \mathrm{g}$ polyinosinic:polycytidylic acid (poly (I:C)) dissolved in $100 \mu \mathrm{L}$ of phosphate-buffered saline (PBS). The mild COVID-19 group received the fifth dose of SARS-CoV-2 spike protein and poly (I:C) in $100 \mu \mathrm{L}$ of PBS. The control group received $100 \mu \mathrm{L}$ intratracheal PBS. 
medRxiv preprint doi: https://doi.org/10.1101/2022.01.23.22269723; this version posted January 24, 2022. The copyright holder for this preprint (which was not certified by peer review) is the author/funder, who has granted medRxiv a license to display the preprint in It is made available under a CC-BY-NC 4.0 International license .

To evaluate effects of anti-HMGB-1 neutralizing antibodies in severe COVID-19 animal model, six animals were randomly placed in either anti-HMGB-1 antibody or isotype control groups ( $\mathrm{n}=3$ for each). The severe COVID-19 animal model was established as described above. Then, $100 \mu \mathrm{g}$ anti-HMGB-1 neutralizing or isotype control antibodies dissolved in $100 \mu \mathrm{L}$ PBS were intravenously administered via the tail vein $4 \mathrm{~h}$ after intratracheal instillation.

\section{Analysis of the BALF of mouse models of COVID-19}

BALF leukocyte and protein levels were quantified as described previously. Concentrations of sRAGE, ANG-2, CK18-M30, CK18-M65, and HMGB-1 were measured by ELISAs. Cytokines and chemokines were analyzed using a semiquantitative multiplex cytokine assay.

\section{Immunoblotting}

Mixed lineage kinase domain-like (MLKL), phospho-MLKL, gasdermin D (GSDMD), and cleaved-GSDMD levels in lung tissues were analyzed by immunoblotting. 
medRxiv preprint doi: https://doi.org/10.1101/2022.01.23.22269723; this version posted January 24, 2022. The copyright holder for this preprint (which was not certified by peer review) is the author/funder, who has granted medRxiv a license to display the preprint in It is made available under a CC-BY-NC 4.0 International license .

\section{Histological analyses}

Lung tissue sections were stained with hematoxylin and eosin to assess

histopathology. Lung tissue sections were stained with anti-phospho-MLKL and antiGSDMD n-terminal antibodies.

\section{Statistical analyses}

Statistical analyses were performed using Prism 9 (GraphPad Software, La Jolla,

CA). Values of $\mathrm{P}<0.05$ were considered significant. Data from clinical studies were

presented as medians and interquartile ranges (IQRs), and analyzed as non-parametric

data. Log-transformed animal experiment data are presented as means \pm standard

deviation (SD), and analyzed as parametric data. 


\section{Results}

\section{Circulating alveolar tissue injury markers in COVID-19 ARDS}

Forty-eight (18 non-ARDS and 30 ARDS) among a total of 84 patients

hospitalized with COVID-19 during the study period and 18 healthy volunteers matched

as closely as possible for age and sex, were included in analyses. Characteristics of

patients with COVID-19 are presented in Table 1. Patients with ARDS had higher acute

physiology and chronic health evaluation-II (APACHE-II) scores, white blood cell

counts, C-reactive protein (CRP) levels, D-dimer levels, and lower ratios of partial

pressure of arterial oxygen to fraction of inspired oxygen (P/F ratios) and lymphocyte

counts than patients without ARDS. Eight patients with ARDS (26.7\%) died. Among

patients with ARDS, five developed acute kidney injury, with only a small increase in

total bilirubin concentration was observed in several patients. Thus, organ dysfunction

in most patients was primarily limited to the lungs.

We evaluated the circulating levels of three alveolar tissue injury markers: an

alveolar epithelial injury marker (sRAGE) $(19,20)$ and an endothelial injury marker

(ANG-2)(21, 22), along with an alveolar permeability indicator (SP-D)(23, 24). All the

alveolar tissue injury markers levels after admission were significantly higher in

patients with ARDS versus healthy controls (Fig. 1A-C). However, only serum sRAGE 
and SP-F levels of patients with and without ARDS significantly differed (Fig. 1A-C).

In patients with ARDS, sRAGE levels were significantly elevated immediately after

admission, and gradually decreased thereafter (Fig. 1D, G). On the other hand, ANG-2

and SP-F levels peaked later (Fig. 1E-G). Collectively, these results agree with prior

work that demonstrated that severe alveolar epithelial cell injury at a very early disease

stage is a hallmark of COVID-19-induced $\operatorname{ARDS}(5,6)$.

Circulating levels of epithelial necrosis markers and HMGB-1 are increased in

\section{COVID-19 ARDS}

Next, levels of epithelial cell death markers were evaluated to elucidate the

dominant form of alveolar epithelial cell death at early disease stage of COVID-19-

induced ARDS. Serum levels of CK18-M65 and -M30 antigens were measured to

distinguish alveolar necrosis from apoptosis. CK18 is exclusively expressed in epithelial

cells, and is released upon cell death. The M65 antigen is an indicator of both epithelial

cell necrosis and apoptosis. In contrast, the M30 antigen produced after caspase

cleavage of CK18 is an indicator apoptotic epithelial cell death(25). Although CK18 is

expressed in all kinds of epithelial cells, it thought to be derived from alveolar epithelial

cells in this cohort because the organ damage was limited almost exclusively to the 
lungs. Levels of both M65 and M30 at admission was positively correlated with disease severity in patients with COVID-19 (Fig. 2A, B). The M30/M65 ratio, which is an indicator of apoptosis, was significantly lower in ARDS patients [median: $31.5 \%$, IQR: 19.4-43.3] than healthy controls [median: 98.9\%, IQR: 83.1-100.0] or non-ARDS patients [median: 46.7 \%, IQR: 36.6-80.5] (Fig. 2C), indicating that epithelial cell death in COVID-19 ARDS is mainly due to necrosis. Additionally, levels of HMGB-1, a kind of DAMPs released from necrotic cells, were significantly elevated in ARDS patients versus non-ARDS patients and healthy controls (Fig. 2D). The analysis of correlations among these biomarkers demonstrated that HMGB-1 levels were most strongly correlated with M65 levels, suggesting that epithelial cell death contributes to HMGB-1 release to circulation (Fig. E1 in the online data supplement).

Intratracheal instillation of SARS-CoV-2 spike proteins combined with poly (I:C) to mice induces lung injury mimicking COVID-19-induced ARDS

To elucidate mechanisms of alveolar epithelial cell death in COVID-19-induced ARDS, a COVID-19 mouse model was established. Previously, it was reported that innate immune responses to components of SARS-CoV-2 are principal drivers of inflammation and alveolar tissue injury in COVID-19(26-28). As expected, a 
preliminary experiment demonstrated that the SARS-CoV-2 spike protein combined with poly (I:C), a synthetic analog of double-stranded RNA induced severe lung injury in wild-type C57BL6/J mice (Fig. E2 in the online data supplement). Based on these findings, mice intratracheally instilled with the SARS-CoV-2 spike protein and poly (I:C) were used as animal models of severe and mild COVID-19. In the COVID-19 animal models, leukocytes infiltration (Fig. 3A), increased levels of protein, sRAGE, and ANG-2 in BALF (Fig. 3A-D), and lung tissue injury (Fig. 3E) were observed. Further, levels of several chemokines and cytokines previously reported to be elevated in COVID-19 patients $(29,30)$ were significantly increased in the BALF of animal models of severe COVID-19 versus controls (Fig. 3F).

Necrosis, including necroptosis and pyroptosis, is a primary form of alveolar epithelial cell death in mouse models of severe COVID-19

Both M30 and M65 levels were increased in the BALF of COVID-19 models versus controls (Fig. 4A, B), indicating that both necrosis and apoptosis are involved in alveolar epithelial cell death. M30/M65 ratio, an indicator of apoptosis fraction relative to total epithelial cell death, decreased as lung injury increased in severity, as was observed in COVID-19 patients (Fig. 4C). Additionally, HMGB-1 levels were 
medRxiv preprint doi: https://doi.org/10.1101/2022.01.23.22269723; this version posted January 24, 2022. The copyright holder for this preprint (which was not certified by peer review) is the author/funder, who has granted medRxiv a license to display the preprint in It is made available under a CC-BY-NC 4.0 International license .

significantly elevated in severe COVID-19 animal model versus the other two groups

(Fig.4D). Taken together, these results demonstrated that animal models of severe

COVID-19 exhibit the same pattern of alveolar epithelial cell death as COVID-19

patients with ARDS.

Next, we evaluated whether some forms of programmed necrosis are involved in alveolar epithelial cell death animal models of COVID-19. Necroptosis and pyroptosis are two types of programmed necrosis that are induced by inflammation(31). In lung tissues of animal models of severe COVID-19, levels of phospho-MLKL and cleaved GSDMD, executioners of necroptosis(32, 33) and pyroptosis(34), respectively, were significantly elevated versus the other two groups (Fig. 4E, F, Fig. E3 in the online data supplement)). Moreover, immunohistochemical analysis demonstrated that both phospho-MLKL and GSDMD are localized within alveolar walls (Fig. 4G). Collectively, these results indicate that necroptosis and pyroptosis contribute to alveolar epithelial cell death in COVID-19-induced ARDS. 
medRxiv preprint doi: https://doi.org/10.1101/2022.01.23.22269723; this version posted January 24, 2022. The copyright holder for this preprint (which was not certified by peer review) is the author/funder, who has granted medRxiv a license to display the preprint in It is made available under a CC-BY-NC 4.0 International license .

Necrosis of alveolar epithelial cells seems to occur in very early stages of the pathogenesis of COVID-19-induced ARDS, and it is difficult to prevent alveolar epithelial necrosis prior to hospital admission. Therefore, we evaluated whether inhibition of one of DAMPs, HMGB-1, attenuated alveolar tissue injury in a severe COVID-19 animal model. Treatment with the anti-HMGB-1 neutralizing antibody $4 \mathrm{~h}$ after intratracheal instillation of poly (I:C) and the SARS-CoV-2 spike protein significantly decreased BALF levels of leukocyte infiltration, total protein, sRAGE, and ANG-2 (Fig. 5 A-D). These results suggest that DAMPs such as HMGB-1 are promising therapeutic targets that may be used to prevent the aggravation of COVID19-induced ARDS after hospital admission. 
medRxiv preprint doi: https://doi.org/10.1101/2022.01.23.22269723; this version posted January 24,2022 . The copyright holder for this preprint (which was not certified by peer review) is the author/funder, who has granted medRxiv a license to display the preprint in It is made available under a CC-BY-NC 4.0 International license.

\section{Discussion}

In the present study, we demonstrated that necrosis is the main form of alveolar epithelial cell death in COVID-19-induced ARDS. Moreover, two forms of programmed necrosis, necroptosis and pyroptosis, were involved in the alveolar epithelial necrosis in mouse models of severe COVID-19. Animal experiments also suggested that DAMPs released from necrotic alveolar epithelial cells such as HMGB-1 are potential drivers of disease exacerbation in COVID-19-induced ARDS.

Alveolar tissue injury in severe COVID-19 is aggravated after passing the peak viral load(3, 4). Therefore, hyperinflammatory responses only against SARS-CoV-2 per se cannot fully explain mechanisms that underly disease progression. Recently, we published findings suggesting that alveolar epithelial injury at a very early disease stage may trigger subsequent COVID-19 progression(5). The present study indicates that initial alveolar epithelial necrosis, and the subsequent release of DAMPs may exacerbate alveolar tissue injury, which can progress even after viral loads have peaked.

Previously, it was shown that both necrosis and apoptosis are involved in alveolar epithelial cell injury in ARDS(8). Because apoptosis can be easily assessed by TUNEL staining or caspase detection, the contribution of alveolar epithelial apoptosis in ARDS has been extensively studied(7). However, we recently demonstrated that necrosis is the 
medRxiv preprint doi: https://doi.org/10.1101/2022.01.23.22269723; this version posted January 24, 2022. The copyright holder for this preprint (which was not certified by peer review) is the author/funder, who has granted medRxiv a license to display the preprint in It is made available under a CC-BY-NC 4.0 International license.

dominant form of alveolar epithelial cell death in LPS-induced ARDS by quantification of CK18-M30 and M65 in addition to cell labeling techniques(9). In particular, quantification of CK18-M30 and M65 levels using commercially available ELISA kit can be applied for evaluation of epithelial apoptosis and necrosis in clinical setting. In fact, patterns of epithelial cell death such as sepsis $(35,36)$ and graft rejection after lung transplantation(37) have been analyzed previously. This is the first study to suggest that necrosis is the primary form of alveolar epithelial cell death in human ARDS, similar to LPS-induced animal models of ARDS. Further studies will be needed to identify alveolar patterns of epithelial cell death in ARDS that is induced by disease etiologies other than COVID-19.

Necrosis was previously thought to cause accidental cell death. However, it has been demonstrated that some forms of necrosis, which are called as programmed necrosis, are regulated via molecular pathways(38). Several animal studies have demonstrated that programmed necrosis is involved in alveolar epithelial cell death in ARDS(10-13). Moreover, studies have suggested that SARS-CoV-2 activates intracellular necroptosis and pyroptosis pathways $(31,39,40)$, and it has been reported that the circulating level of receptor-interacting protein kinase 3, a kinase required for necroptosis, is elevated in critically ill patients with COVID-19(41). In line with 
medRxiv preprint doi: https://doi.org/10.1101/2022.01.23.22269723; this version posted January 24, 2022. The copyright holder for this preprint (which was not certified by peer review) is the author/funder, who has granted medRxiv a license to display the preprint in It is made available under a CC-BY-NC 4.0 International license.

findings of these studies, our animal experiments suggest that necroptosis and pyroptosis are involved in alveolar epithelial cell death in COVID-19 ARDS.

The release of DAMPs to extracellular spaces is a characteristic of necrosis that distinguishes it from apoptosis(42). Several previous studies have also reported that circulating levels of DAMPs, such as HMGB-1 $(43,44)$ or mitochondrial DNA(45) are elevated in severe COVID-19. Alveolar epithelial necrosis likely occurs very early in COVID-19 progression. The prevention of necrosis prior to the appearance of clinical symptoms is difficult; therefore, a strategy for preventing DAMPs-mediated disease aggravation is needed. Our animal study demonstrated that the inhibition of DAMPs efficiently attenuates disease progression. Further studies, including clinical trials, are warranted to investigate the clinical efficacy of DAMP inhibition in patients with COVID-19 ARDS.

In the present study, an animal model mimicking COVID-19 was established by administering the SARS-CoV-2 spike protein combined with poly (I:C). The same approach has been used in some studies $(46,47)$. Animal models treated with infectious strains of SARS-CoV-2 are often ideal models for COVID-19; however, use of infectious viruses in animal experiments can be difficult. First, SARS-CoV-2 infection does not occur in wild-type mice or rats. For infection to occur, expression of the human 
medRxiv preprint doi: https://doi.org/10.1101/2022.01.23.22269723; this version posted January 24, 2022. The copyright holder for this preprint (which was not certified by peer review) is the author/funder, who has granted medRxiv a license to display the preprint in It is made available under a CC-BY-NC 4.0 International license .

ACE receptor is needed. Second, facilities and equipment are needed to prevent the infection of researchers. Although the pathogenicity of SARS-CoV-2 is complex, stimulation of pathogen-associated pattern recognition receptors including toll-like receptors and retinoic acid-inducible gene-I receptors by viral components is the principal driver of lung inflammation, and subsequent alveolar tissue damage. In addition to inflammatory signatures, alveolar cell death patterns in our COVID-19 animal model were similar to those observed in human COVID-19. Our results highlight the utility of investigating the pathophysiology and treatment of COVID-19 using animal models established with components of SARS-CoV-2.

Our data suggest that plasma M30/M65 ratio (an indicator of apoptosis in relation to total levels of epithelial cell death) is a potential marker of COVID-19 severity. Our findings agreed with a previous study that showed M30/M65 ratios of hospitalized COVID-19 patients were lower than those of non-hospitalized patients(48).

Additionally, some studies have indicated that subtypes of COVID-19 respond to treatments differently $(49,50)$. M30/M65 ratio may serve as a marker for selecting patients likely to benefit from anti-DAMPs treatment.

This study has some limitations. First, only patients admitted to a single center were included in the analysis due to the limited availability of clinical samples. Further 
medRxiv preprint doi: https://doi.org/10.1101/2022.01.23.22269723; this version posted January 24, 2022. The copyright holder for this preprint (which was not certified by peer review) is the author/funder, who has granted medRxiv a license to display the preprint in It is made available under a CC-BY-NC 4.0 International license .

studies that use samples from multiple centers several countries are warranted. Second, our animal model was created by exposing mice to components of SARS-CoV-2, and not an infectious strain of SARS-CoV-2. Despite this, the observation of a COVID-19like pathology supports the use of our animal model. Importantly, use of a noninfectious model is convenient for laboratories that do not specialize in infectious disease research. Third, the efficacy of inhibiting a single DAMP, HMGB-1, was evaluated. Several DAMPs are released from necrotic cells; therefore, future studies that investigate whether other DAMP are promising therapeutic targets for COVID-19 are warranted.

\section{Conclusion}

In conclusion, our data indicate that necrosis, including necroptosis and pyroptosis, is the primary form of alveolar epithelial cell death in COVID-19-induced ARDS.

DAMPs released from necrotic alveolar epithelial cells are potential drivers of progressive alveolar tissue damage in COVID-19; therefore, they are promising targets for preventing the aggravation of ARDS in patients with COVID-19. 
medRxiv preprint doi: https://doi.org/10.1101/2022.01.23.22269723; this version posted January 24, 2022. The copyright holder for this preprint (which was not certified by peer review) is the author/funder, who has granted medRxiv a license to display the preprint in It is made available under a CC-BY-NC 4.0 International license .

\section{Acknowledgements}

We would like to thank Ms. Yuki Yuba (Department of Anesthesiology and Critical

Care Medicine) for technical assistance. We also thank Department of Emergency

Medicine (Prof. Ichiro Takeuchi), Department of Microbiology (Prof. Akihide Ryo), and Yokohama City University Center for Novel and Exploratory Clinical Trials for collecting and providing the blood samples. This work was partly supported by AMED under Grant Number JP20he0522001 and JSPS KAKENHI Grant Number 21K16575, and Grant for 2020-2021 Research Development Fund of Yokohama City University. 


\section{References}

1. Polak SB, Gool ICV, Cohen D, Thüsen JH von der, Paassen J van. A systematic review of pathological findings in COVID-19: a pathophysiological timeline and possible mechanisms of disease progression. Modern Pathol 2020;33:2128-2138.

2. Gerard L, Lecocq M, Bouzin C, Hoton D, Schmit G, Pereira JP, Montiel V, Plante-

Bordeneuve T, Laterre P-F, Pilette C. Increased Angiotensin-Converting Enzyme 2 and Loss of Alveolar Type II Cells in COVID-19-related Acute Respiratory Distress Syndrome. Am J Resp Crit Care 2021;204:1024-1034.

3. Stanleyraj JS, Sethuraman N, Gupta R, Thiruvoth S, Gupta M, Ryo A. Treating COVID-19: are we missing out the window of opportunity? J Antimicrob Chemoth 2020;76:dkaa442.

4. Munker D, Osterman A, Stubbe H, Muenchhoff M, Veit T, Weinberger T, Barnikel M, Mumm J-N, Milger K, Khatamzas E, Klauss S, Scherer C, Hellmuth JC, GiessenJung C, Zoller M, Herold T, Stecher S, Toni EN de, Schulz C, Kneidinger N, Keppler OT, Behr J, Mayerle J, Munker S. Dynamics of SARS-CoV-2 shedding in the respiratory tract depends on the severity of disease in COVID-19 patients. European Respir J 2021;58:2002724. 
medRxiv preprint doi: https://doi.org/10.1101/2022.01.23.22269723; this version posted January 24, 2022. The copyright holder for this preprint (which was not certified by peer review) is the author/funder, who has granted medRxiv a license to display the preprint in It is made available under a CC-BY-NC 4.0 International license .

5. Tojo K, Yamamoto N, Mihara T, Abe M, Goto T. Distinct temporal characteristics of circulating alveolar epithelial and endothelial injury markers in ARDS with COVID-19. Crit Care 2021;25:169.

6. Leisman DE, Mehta A, Thompson BT, Charland NC, Gonye ALK, Gushterova I, Kays KR, Khanna HK, LaSalle TJ, Lavin-Parsons KM, Lilley BM, Lodenstein CL, Manakongtreecheep K, Margolin JD, McKaig BN, Rojas-Lopez M, Russo BC, Sharma N, Tantivit J, Thomas MF, Parry BA, Villani A-C, Sade-Feldman M, Hacohen N, Filbin MR, Goldberg MB. Alveolar, Endothelial, and Organ Injury Marker Dynamics in Severe COVID-19. Am J Resp Crit Care 2021;doi:10.1164/rccm.202106-1514oc.

7. Martin TR. Apoptosis and Epithelial Injury in the Lungs. Proceedings of the American Thoracic Society 2005;2:214-220.

8. Tang PS, Mura M, Seth R, Liu M. Acute lung injury and cell death: how many ways can cells die? Am J Physiol-lung C 2008;294:L632-L641.

9. Tamada N, Tojo K, Yazawa T, Goto T. Necrosis Rather Than Apoptosis is the Dominant form of Alveolar Epithelial Cell Death in Lipopolysaccharide-Induced Experimental Acute Respiratory Distress Syndrome Model. Shock 2020;54:128-139. 
10. Zhao H, Ning J, Lemaire A, Koumpa F-S, Sun JJ, Fung A, Gu J, Yi B, Lu K, Ma D.

Necroptosis and parthanatos are involved in remote lung injury after receiving ischemic renal allografts in rats. Kidney Int 2015;87:738-748.

11. Wang L, Wang T, Li H, Liu Q, Zhang Z, Xie W, Feng Y, Socorburam T, Wu G, Xia

Z, Wu Q. Receptor Interacting Protein 3-Mediated Necroptosis Promotes

Lipopolysaccharide-Induced Inflammation and Acute Respiratory Distress Syndrome in

Mice. In: Ahmad S, editor. PLoS ONE 2016;11:e0155723.

12. Siempos II, Ma KC, Imamura M, Baron RM, Fredenburgh LE, Huh J-W, Moon J-S,

Finkelsztein EJ, Jones DS, Lizardi MT, Schenck EJ, Ryter SW, Nakahira K, Choi

AMK. RIPK3 mediates pathogenesis of experimental ventilator-induced lung injury. Jci

Insight 2018;3:e97102.

13. Zhao H, Chen Q, Huang H, Suen KC, Alam A, Cui J, Ciechanowicz S, Ning J, Lu

K, Takata M, Gu J, Ma D. Osteopontin mediates necroptosis in lung injury after

transplantation of ischaemic renal allografts in rats. Brit J Anaesth 2019;123:519-530.

14. Scaffidi P, Misteli T, Bianchi ME. Release of chromatin protein HMGB1 by

necrotic cells triggers inflammation. Nature 2002;418:191-195. 
medRxiv preprint doi: https://doi.org/10.1101/2022.01.23.22269723; this version posted January 24, 2022. The copyright holder for this preprint (which was not certified by peer review) is the author/funder, who has granted medRxiv a license to display the preprint in It is made available under a CC-BY-NC 4.0 International license.

15. Denning N-L, Aziz M, Gurien SD, Wang P. DAMPs and NETs in Sepsis. Front Immunol 2019;10:2536.

16. Ivanisenko NV, Seyrek K, Kolchanov NA, Ivanisenko VA, Lavrik IN. The role of death domain proteins in host response upon SARS-CoV-2 infection: modulation of programmed cell death and translational applications. Cell Death Discov 2020;6:101.

17. Land WG. Role of DAMPs in respiratory virus-induced acute respiratory distress syndrome - with a preliminary reference to SARS-CoV-2 pneumonia. Genes Immun 2021;22:1-20.

18. Force ADT, Ranieri VM, Rubenfeld GD, Thompson BT, Ferguson ND, Caldwell E,

Fan E, Camporota L, Slutsky AS. Acute Respiratory Distress Syndrome: The Berlin

Definition. Jama 2012;307:2526-2533.

19. Uchida T, Shirasawa M, Ware LB, Kojima K, Hata Y, Makita K, Mednick G, Matthay ZA, Matthay MA. Receptor for Advanced Glycation End-Products Is a Marker of Type I Cell Injury in Acute Lung Injury. Am J Resp Crit Care 2006;173:1008-1015. 
20. Calfee CS, Ware LB, Eisner MD, Parsons PE, Thompson BT, Wickersham N,

Matthay MA, Network NA. Plasma receptor for advanced glycation end products and

clinical outcomes in acute lung injury. Thorax 2008;63:1083.

21. Heijden M van der, Amerongen GP van N, Koolwijk P, Hinsbergh VWM van,

Groeneveld ABJ. Angiopoietin-2, permeability oedema, occurrence and severity of

ALI/ARDS in septic and non-septic critically ill patients. Thorax 2008;63:903.

22. Calfee CS, Gallagher D, Abbott J, Thompson BT, Matthay MA, Network NA.

Plasma angiopoietin-2 in clinical acute lung injury. Crit Care Med 2012;40:1731-1737.

23. Eisner MD, Parsons P, Matthay MA, Ware L, Greene K, Network ARDS. Plasma

surfactant protein levels and clinical outcomes in patients with acute lung injury. Thorax

2003;58:983.

24. Cheng IW, Ware LB, Greene KE, Nuckton TJ, Eisner MD, Matthay MA. Prognostic value of surfactant proteins $\mathrm{A}$ and $\mathrm{D}$ in patients with acute lung injury*. Crit Care Med $2003 ; 31: 20-27$

25. Kramer G, Erdal H, Mertens HJMM, Nap M, Mauermann J, Steiner G, Marberger M, Bivén K, Shoshan MC, Linder S. Differentiation between Cell Death Modes Using 
Measurements of Different Soluble Forms of Extracellular Cytokeratin 18. Cancer Res 2004;64:1751-1756.

26. Zhao Y, Kuang M, Li J, Zhu L, Jia Z, Guo X, Hu Y, Kong J, Yin H, Wang X, You F. SARS-CoV-2 spike protein interacts with and activates TLR41. Cell Res 2021;31:818-820.

27. Zheng M, Karki R, Williams EP, Yang D, Fitzpatrick E, Vogel P, Jonsson CB, Kanneganti T-D. TLR2 senses the SARS-CoV-2 envelope protein to produce inflammatory cytokines. Nat Immunol 2021;22:829-838.

28. Yamada T, Sato S, Sotoyama Y, Orba Y, Sawa H, Yamauchi H, Sasaki M, Takaoka A. RIG-I triggers a signaling-abortive anti-SARS-CoV-2 defense in human lung cells.

Nat Immunol 2021;22:820-828.

29. Leisman DE, Ronner L, Pinotti R, Taylor MD, Sinha P, Calfee CS, Hirayama AV, Mastroiani F, Turtle CJ, Harhay MO, Legrand M, Deutschman CS. Cytokine elevation in severe and critical COVID-19: a rapid systematic review, meta-analysis, and comparison with other inflammatory syndromes. Lancet Respir Medicine 2020;8:12331244. 
medRxiv preprint doi: https://doi.org/10.1101/2022.01.23.22269723; this version posted January 24, 2022. The copyright holder for this preprint (which was not certified by peer review) is the author/funder, who has granted medRxiv a license to display the preprint in It is made available under a CC-BY-NC 4.0 International license .

30. McElvaney OJ, McEvoy NL, McElvaney OF, Carroll TP, Murphy MP, Dunlea DM,

Choileáin ON, Clarke J, O’Connor E, Hogan G, Ryan D, Sulaiman I, Gunaratnam C,

Branagan P, O’Brien ME, Morgan RK, Costello RW, Hurley K, Walsh S, Barra E de,

McNally C, McConkey S, Boland F, Galvin S, Kiernan F, O’Rourke J, Dwyer R, Power

M, Geoghegan P, et al. Characterization of the Inflammatory Response to Severe

COVID-19 Illness. Am J Resp Crit Care 2020;202:812-821.

31. Karki R, Sharma BR, Tuladhar S, Williams EP, Zalduondo L, Samir P, Zheng M,

Sundaram B, Banoth B, Malireddi RKS, Schreiner P, Neale G, Vogel P, Webby R,

Jonsson CB, Kanneganti T-D. Synergism of TNF- $\alpha$ and IFN- $\gamma$ Triggers Inflammatory

Cell Death, Tissue Damage, and Mortality in SARS-CoV-2 Infection and Cytokine

Shock Syndromes. Cell 2021;184:149-168.e17.

32. Zhao J, Jitkaew S, Cai Z, Choksi S, Li Q, Luo J, Liu Z-G. Mixed lineage kinase domain-like is a key receptor interacting protein 3 downstream component of TNFinduced necrosis. Proceedings of the National Academy of Sciences 2012;109:53225327.

33. Hildebrand JM, Tanzer MC, Lucet IS, Young SN, Spall SK, Sharma P, Pierotti C,

Garnier J-M, Dobson RCJ, Webb AI, Tripaydonis A, Babon JJ, Mulcair MD, Scanlon 
MJ, Alexander WS, Wilks AF, Czabotar PE, Lessene G, Murphy JM, Silke J.

Activation of the pseudokinase MLKL unleashes the four-helix bundle domain to

induce membrane localization and necroptotic cell death. Proceedings of the National

Academy of Sciences 2014;111:15072-15077.

34. He W, Wan H, Hu L, Chen P, Wang X, Huang Z, Yang Z-H, Zhong C-Q, Han J.

Gasdermin D is an executor of pyroptosis and required for interleukin-1 $\beta$ secretion. Cell

Res 2015;25:1285-1298.

35. Hofer S, Brenner T, Bopp C, Steppan J, Lichtenstern C, Weitz J, Bruckner T, Martin

E, Hoffmann U, Weigand MA. Cell death serum biomarkers are early predictors for

survival in severe septic patients with hepatic dysfunction. Crit Care 2009;13:R93.

36. Lorente L, Martín MM, González-Rivero AF, Ferreres J, Solé-Violán J, Labarta L,

Díaz C, Jiménez A, Borreguero-León JM. Serum Levels of Caspase-Cleaved

Cytokeratin-18 and Mortality Are Associated in Severe Septic Patients: Pilot Study. In:

Stover CM, editor. PLoS ONE 2014;9:e109618.

37. Hashimoto K, Besla R, Zamel R, Juvet S, Kim H, Azad S, Waddell TK, Cypel M,

Liu M, Keshavjee S. Circulating Cell Death Biomarkers May Predict Survival in

Human Lung Transplantation. Am J Resp Crit Care 2016;194:97-105. 
38. Wallach D, Kang T-B, Dillon CP, Green DR. Programmed necrosis in

inflammation: Toward identification of the effector molecules. Science

2016;352:aaf2154-aaf2154.

39. Li S, Zhang Y, Guan Z, Li H, Ye M, Chen X, Shen J, Zhou Y, Shi Z-L, Zhou P,

Peng K. SARS-CoV-2 triggers inflammatory responses and cell death through caspase-

8 activation. Signal Transduct Target Ther 2020;5:235.

40. Ferren M, Favède V, Decimo D, Iampietro M, Lieberman NAP, Weickert J-L,

Pelissier R, Mazelier M, Terrier O, Moscona A, Porotto M, Greninger AL, Messaddeq

N, Horvat B, Mathieu C. Hamster organotypic modeling of SARS-CoV-2 lung and

brainstem infection. Nat Commun 2021;12:5809.

41. Nakamura H, Kinjo T, Arakaki W, Miyagi K, Tateyama M, Fujita J. Serum levels of receptor-interacting protein kinase-3 in patients with COVID-19. Crit Care

2020;24:484.

42. Gong T, Liu L, Jiang W, Zhou R. DAMP-sensing receptors in sterile inflammation and inflammatory diseases. Nat Rev Immunol 2020;20:95-112. 
43. Chen R, Huang Y, Quan J, Liu J, Wang H, Billiar TR, Lotze MT, Zeh HJ, Kang R,

Tang D. HMGB1 as a potential biomarker and therapeutic target for severe COVID-19.

Heliyon 2020;6:e05672.

44. Sivakorn C, Dechsanga J, Jamjumrus L, Boonnak K, Schultz MJ, Dondorp AM,

Phumratanaprapin W, Ratanarat R, Naorungroj T, Wattanawinitchai P, Siripoon T,

Duangdee C, Techarang T. High Mobility Group Box 1 and Interleukin 6 at Intensive

Care Unit Admission as Biomarkers in Critically Ill COVID-19 Patients. Am J Tropical

Medicine Hyg 2021;105:73-80.

45. Scozzi D, Cano M, Ma L, Zhou D, Zhu JH, O’Halloran JA, Goss CW, Rauseo AM,

Liu Z, Sahu SK, Peritore V, Rocco M, Ricci A, Amodeo R, Aimati L, Ibrahim M,

Hachem RR, Kreisel D, Mudd PA, Kulkarni HS, Gelman AE. Circulating mitochondrial

DNA is an early indicator of severe illness and mortality from COVID-19. Jci Insight

2021;6:

46. Gu T, Zhao S, Jin G, Song M, Zhi Y, Zhao R, Ma F, Zheng Y, Wang K, Liu H, Xin

M, Han W, Li X, Dong CD, Liu K, Dong Z. Cytokine Signature Induced by SARS-

CoV-2 Spike Protein in a Mouse Model. Front Immunol 2021;11:621441. 
medRxiv preprint doi: https://doi.org/10.1101/2022.01.23.22269723; this version posted January 24, 2022. The copyright holder for this preprint (which was not certified by peer review) is the author/funder, who has granted medRxiv a license to display the preprint in It is made available under a CC-BY-NC 4.0 International license.

47. Biancatelli RMLC, Solopov PA, Sharlow ER, Lazo JS, Marik PE, Catravas JD. The SARS-CoV-2 spike protein subunit S1 induces COVID-19-like acute lung injury in K18-hACE2 transgenic mice and barrier dysfunction in human endothelial cells. Am J Physiology - Lung Cell Mol Physiology 2021;321:L477-L484.

48. Henry BM, Cheruiyot I, Benoit SW, Sanchis-Gomar F, Lippi G, Benoit J.

Cytokeratin 18 cell death assays as biomarkers for quantification of apoptosis and necrosis in COVID-19: a prospective, observational study. J Clin Pathol 2021; jclinpath2020-207242.doi:10.1136/jclinpath-2020-207242.

49. Ranjeva S, Pinciroli R, Hodell E, Mueller A, Hardin CC, Thompson BT, Berra L. Identifying clinical and biochemical phenotypes in acute respiratory distress syndrome secondary to coronavirus disease-2019. Eclinicalmedicine 2021;34:100829.

50. Sinha P, Furfaro D, Cummings MJ, Abrams D, Delucchi K, Maddali MV, He J, Thompson A, Murn M, Fountain J, Rosen A, Robbins-Juarez SY, Adan MA, Satish T, Madhavan M, Gupta A, Lyashchenko AK, Agerstrand C, Yip NH, Burkart KM, Beitler JR, Baldwin MR, Calfee CS, Brodie D, O’Donnell MR. Latent Class Analysis Reveals COVID-19-related Acute Respiratory Distress Syndrome Subgroups with Differential Responses to Corticosteroids. Am J Resp Crit Care 2021;204:1274-1285. 
medRxiv preprint doi: https://doi.org/10.1101/2022.01.23.22269723; this version posted January 24, 2022. The copyright holder for this preprint (which was not certified by peer review) is the author/funder, who has granted medRxiv a license to display the preprint in It is made available under a CC-BY-NC 4.0 International license. 


\section{Table.1}

The clinical characteristics in ARDS and non-ARDS patients with COVID-19.

$\begin{array}{llll} & \text { Non-ARDS }(\mathrm{n}=18) & \text { ARDS }(\mathrm{n}=30) & \mathrm{p} \text {-Value } \\ \text { Age }(\text { years }) & 65(49-74) & 69(63-76) & 0.2288 \\ \text { Males/Females } & 13 / 5 & 23 / 7 & 0.7519 \\ \text { APACHE2 score } & 8.0(6.5-10.3) & 12.5(9.0-15.0) & * 0.0005 \\ \text { P/F ratio at admission } & 405.0(323.1-448.8) & 170.3(112.8-238.8) & *<0.0001 \\ \text { Mechanical ventilation use } & 0(0.0 \%) & 30(100.0 \%) & *<0.0001 \\ \text { In hospital mortality } & 0(0.0 \%) & 8(26.7 \%) & * 0.0182 \\ \text { Laboratory data on } & & & \\ \text { admission } & & 7850(6175-10675) & * 0.0178 \\ \text { WBC count }(/ \mu \mathrm{L}) & 5550(2925-7700) & 469(273-803) & * 0.0040 \\ \text { Lymphocyte count }(/ \mu \mathrm{L}) & 908(611-1268) & 188.0(138.8-263.5) & 0.7922 \\ \text { Platelet count }\left(\times 10^{3} / \mu \mathrm{L}\right) & 185.5(123.8-270.0) & 1.22(0.99-1.35) & * 0.0185 \\ \text { D-dimer }(\mu \mathrm{g} / \mathrm{mL}) & 0.72(0.00-2.41) & 12.32(7.22-17.22) & *<0.0001 \\ \text { CRP }(\mathrm{mg} / \mathrm{dL}) & 1.04(3.48-4.21) & 0.81(0.63-1.49) & 0.3074 \\ \text { Creatinine }(\mathrm{mg} / \mathrm{dL}) & 0.84(0.72-6.76) & 0.50(0.40-0.90) & 0.8028 \\ \text { Total bilirubin }(\mathrm{mg} / \mathrm{dL}) & 0.55(0.40-0.73) & & \end{array}$

Data are presented as count $(\%)$ or median (IQR). ${ }^{*} \mathrm{p}<0.05$. 
medRxiv preprint doi: https://doi.org/10.1101/2022.01.23.22269723; this version posted January 24, 2022. The copyright holder for this preprint (which was not certified by peer review) is the author/funder, who has granted medRxiv a license to display the preprint in It is made available under a CC-BY-NC 4.0 International license .

\section{Figure Legends}

\section{Figure 1}

Analysis of serum levels of alveolar tissue injury markers using enzyme linked immunosorbent assays (ELISAs). (A) soluble receptors for advanced glycation end products (sRAGE), (B) angiopoietin (ANG)-2, and (C) surfactant protein (SP)-D levels in the serum of patients with COVID-19 with or without acute respiratory distress syndrome (ARDS) at admission (on the first or second hospital day), and healthy controls are shown. Bidaily temporal changes in (D) sRAGE, (E) ANG-2, and (F) SP-D in sera of COVID-19 patients with ARDS during first 8 days after hospital admission are shown. In cases in which multiple values every 2 days were available, mean values were used. When only a single value was available, the value was used. (G) Days in which concentrations of each alveolar tissue injury marker peaked in COVID-19 patients with ARDS are shown. Values are presented as medians with interquartile ranges. ${ }^{*} \mathrm{p}<0.05, * * \mathrm{p}<0.01, * * * \mathrm{p}<0.0001$.

\section{Figure 2}

Serum levels of markers of epithelial cell death and high mobility group box (HMGB)-1 in serum samples of COVID-19 patients with or without acute respiratory distress 
medRxiv preprint doi: https://doi.org/10.1101/2022.01.23.22269723; this version posted January 24, 2022. The copyright holder for this preprint (which was not certified by peer review) is the author/funder, who has granted medRxiv a license to display the preprint in It is made available under a CC-BY-NC 4.0 International license .

syndrome (ARDS) at admission (on the first or second hospital day) and healthy controls. Levels of (A) CK18-M30, an epithelial apoptosis marker, and (B) CK18-M65, an epithelial total cell death marker; (C) CK18-M30/M65 ratio, an indicator of the fraction of epithelial cells undergoing apoptosis versus all types of cell death; and (D) HMGB-1 levels in serum samples of COVID-19 patients with or without ARDS and healthy controls are shown. Values are presented as medians and interquartile ranges. $* \mathrm{p}<0.05, * * \mathrm{p}<0.01, * * * \mathrm{p}<0.0001$

\section{Figure 3}

Use of a mouse model of mild and severe COVID-19. (A) White blood cell count, (B) total protein, (C) soluble receptors for advanced glycation end products (sRAGE), and (D) angiopoietin (ANG)-2 levels in bronchoalveolar lavage fluid (BALF) of mouse models of COVID-19 and controls are shown. (E) Representative lung tissue images of sections stained with hematoxylin and eosin are shown. Values are presented as means \pm standard error. $* \mathrm{p}<0.05, * * \mathrm{p}<0.01, * * * \mathrm{p}<0.0001$. (F) A heatmap constructed from the comprehensive analysis of cytokine levels in the BALF of mouse models of severe

COVID-19 versus control mice. †q-value $<0.05$. 


\section{Figure 4}

Mechanisms of alveolar epithelial cell death in a COVID-19 mouse model. Levels of

(A) CK18-M30 and (B) CK18-M65 in bronchoalveolar lavage fluid (BALF) from a

COVID-19 mouse model are shown. (C) The ratio of CK18-M30/M65, an indicator of

the fraction of apoptosis versus total epithelial cell death, is shown. (D) HMGB-1 levels

in BALF from a COVID-19 mouse model. (E) Images and (F) densitometry of mixed

lineage kinase domain-like (MLKL), p-MLKL, gasdermin D (GSDMD), and cleaved

GSDMD immunoblots of the protein extracted from the lung of a COVID-19 mouse

model are shown. (G) Representative images of the immunohistochemical analysis of p-

MLKL and GSDMD in lung sections of mice are shown. Values are presented as means

\pm standard error. ${ }^{*} \mathrm{p}<0.05, * * \mathrm{p}<0.01, * * * \mathrm{p}<0.0001$

\section{Figure 5}

An analysis of effects of high mobility group box (HMGB)-1 neutralization on alveolar tissue injury in a mouse model of severe COVID-19. (A) Total protein, (B) white blood cell count, (C) soluble receptors for advanced glycation end products (sRAGE), and (D) angiopoietin (ANG)-2 levels in BALF from the mouse model of severe COVID-19 treated with an anti-HMGB-1 neutralizing antibody or an isotype control antibody are 
medRxiv preprint doi: https://doi.org/10.1101/2022.01.23.22269723; this version posted January 24, 2022. The copyright holder for this preprint (which was not certified by peer review) is the author/funder, who has granted medRxiv a license to display the preprint in It is made available under a CC-BY-NC 4.0 International license.

shown. Values are presented as means \pm standard error. ${ }^{*} \mathrm{p}<0.05, * * \mathrm{p}<0.01$ $* * * \mathrm{p}<0.0001$ 


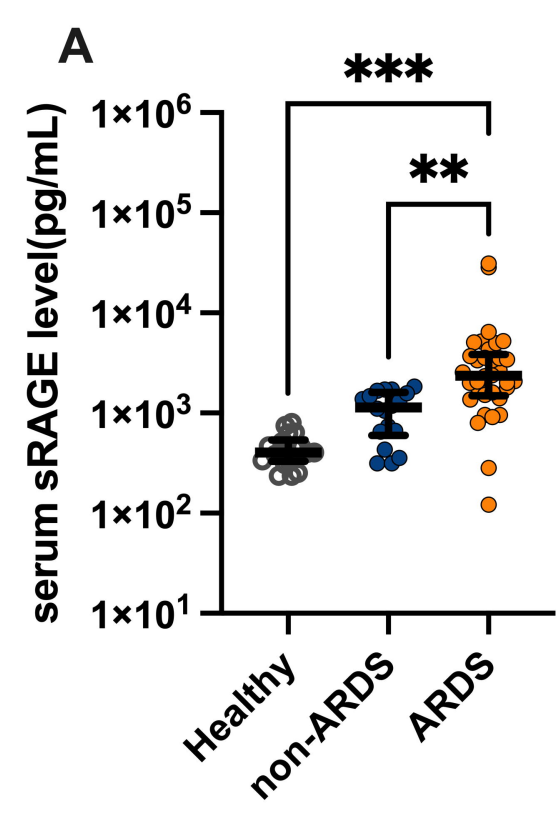

D

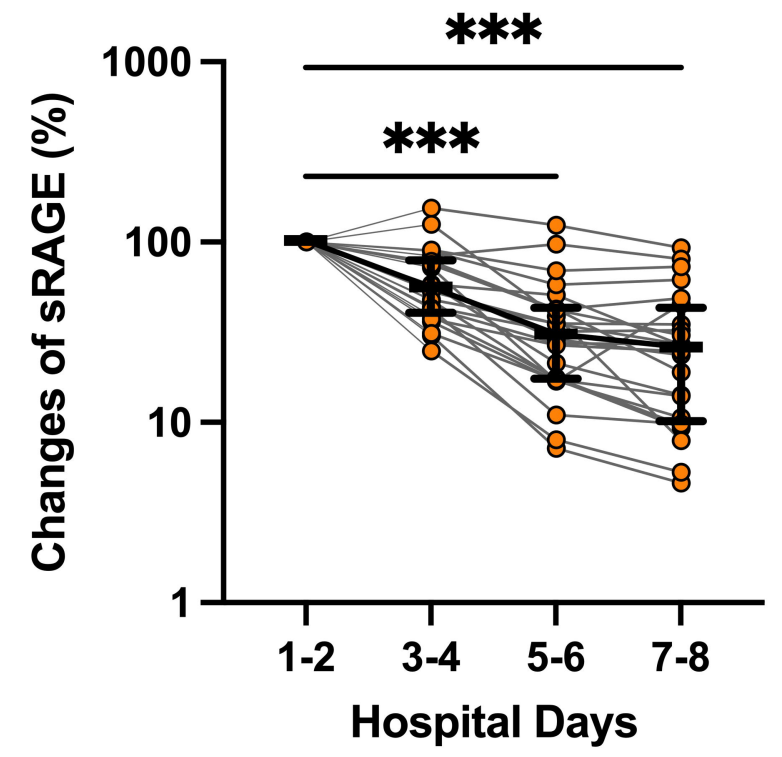

F

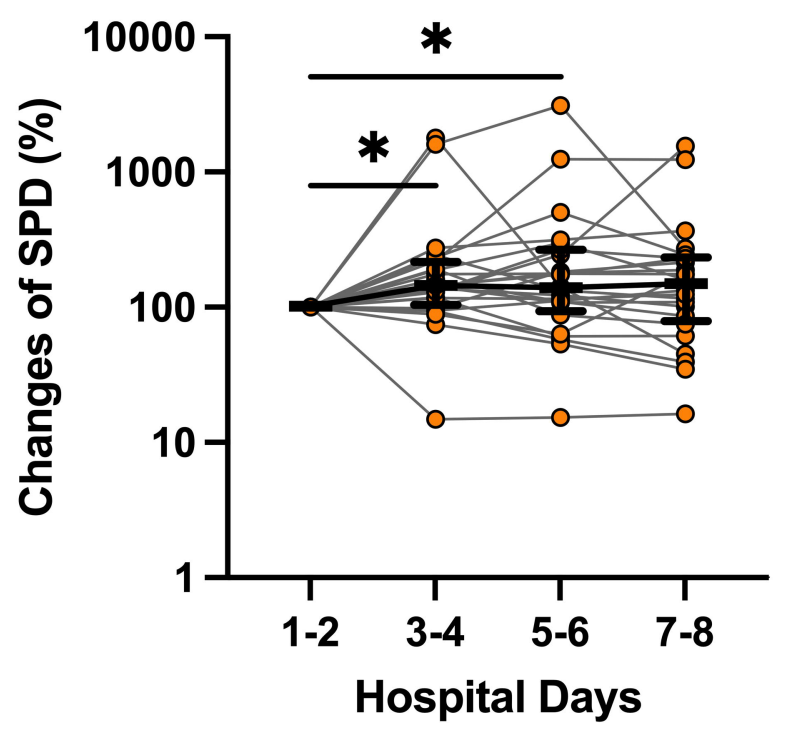

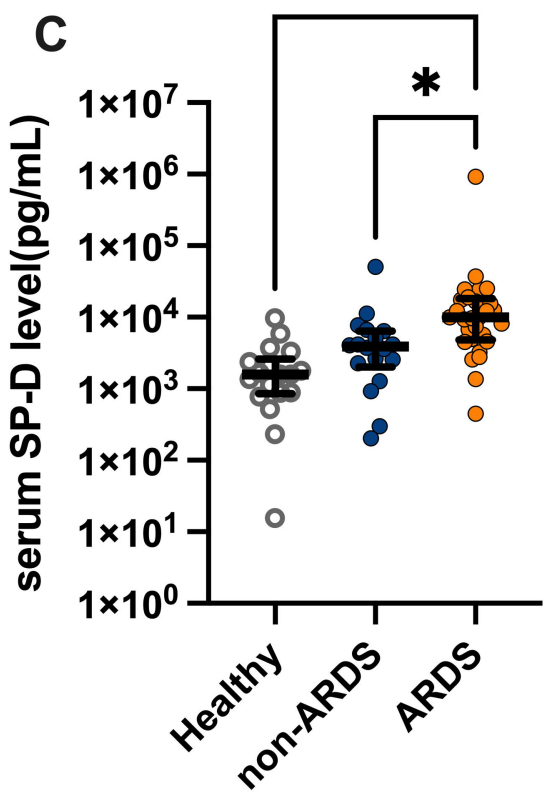

E

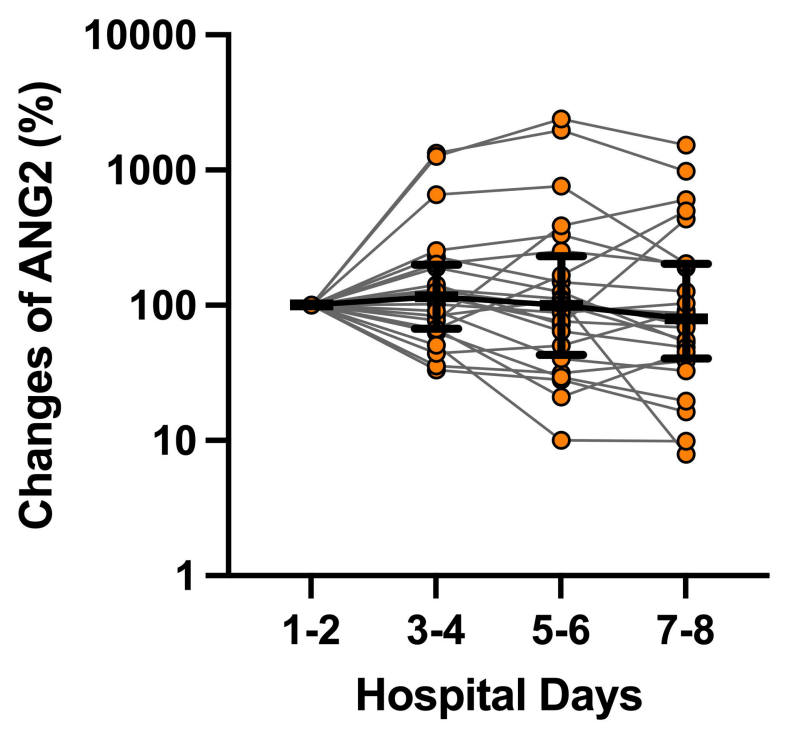

G

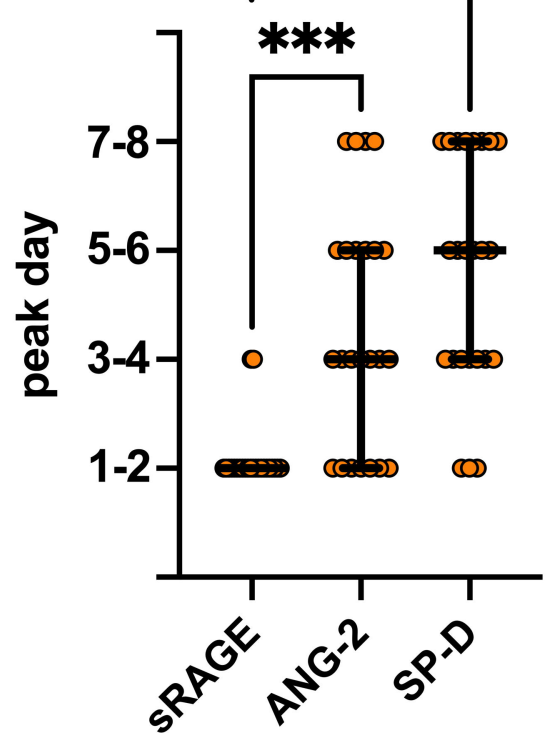



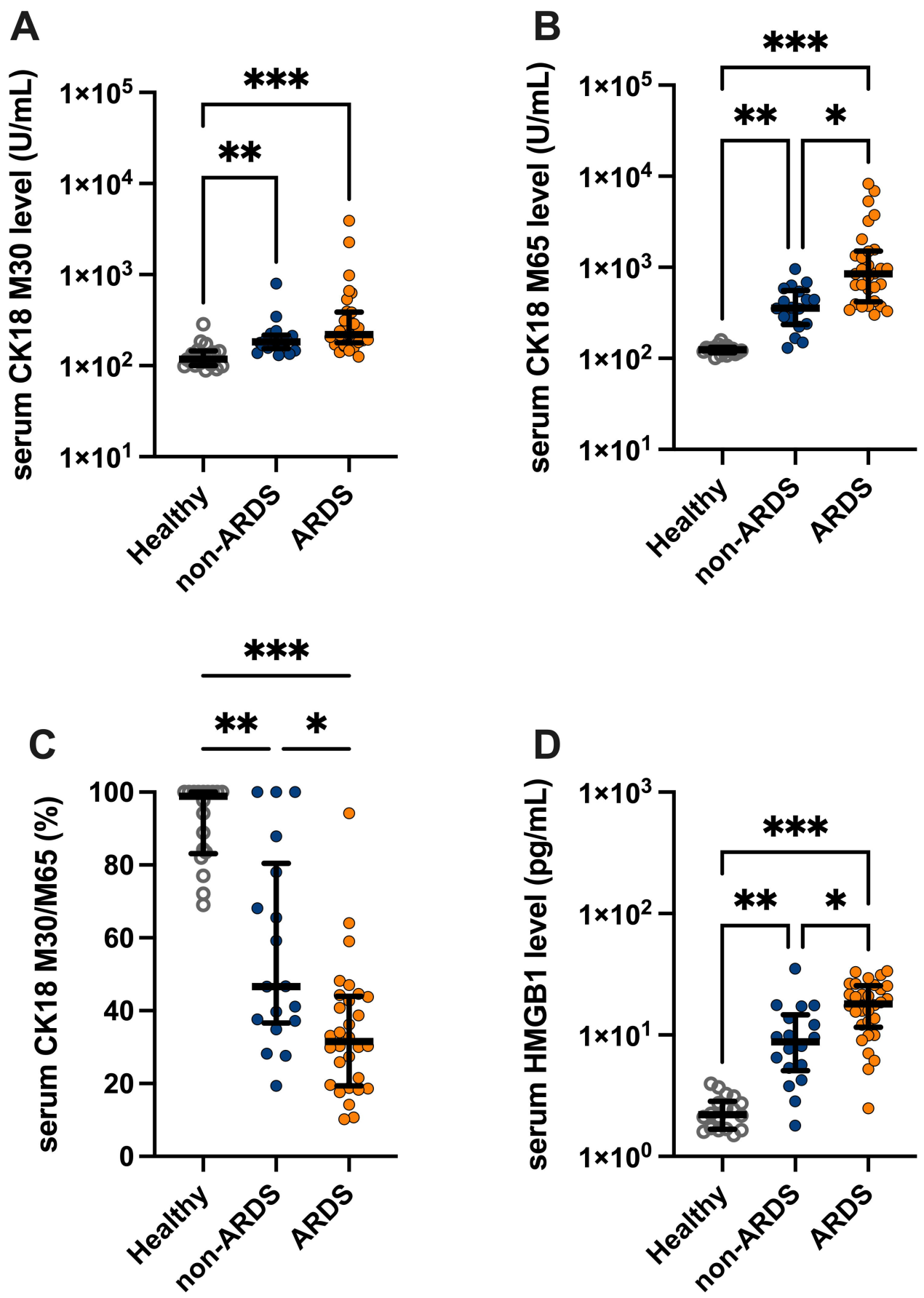


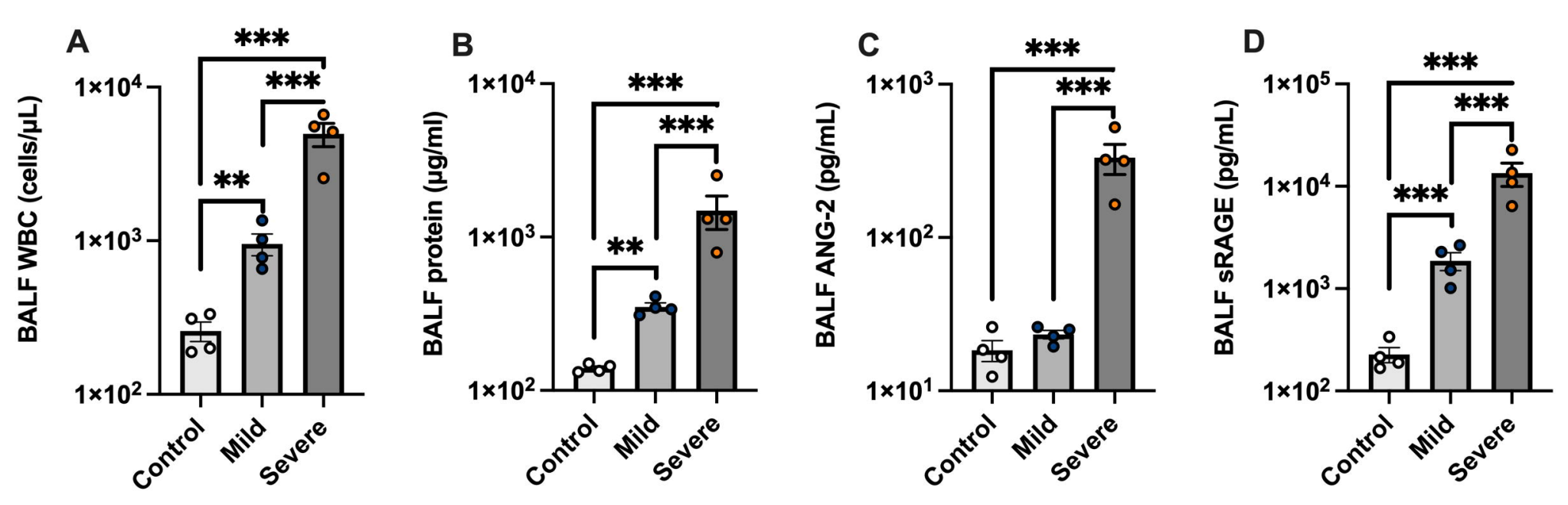

E
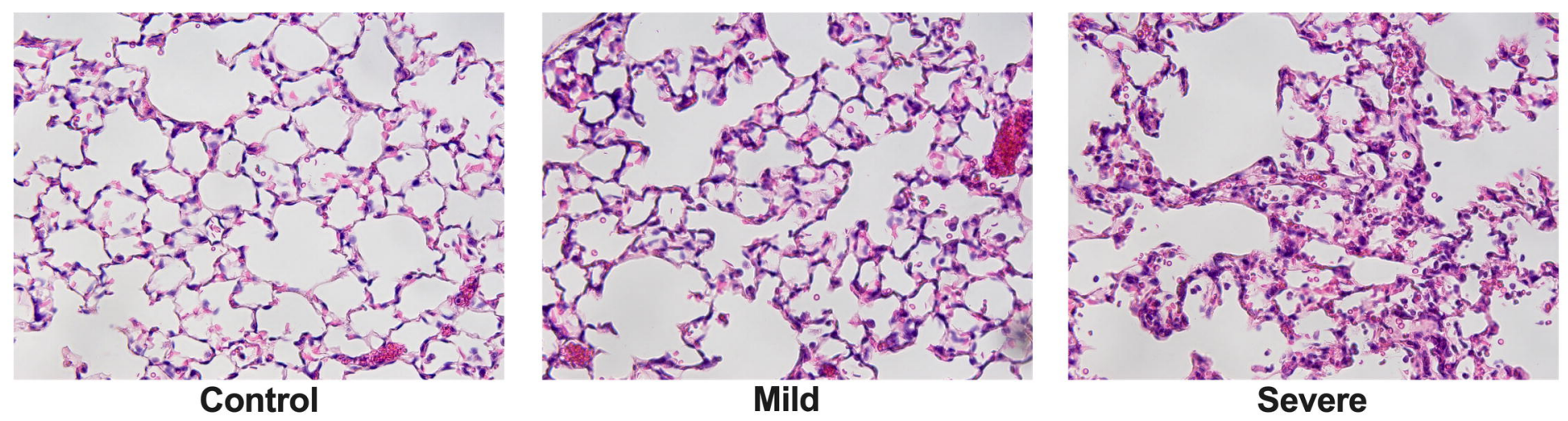

F

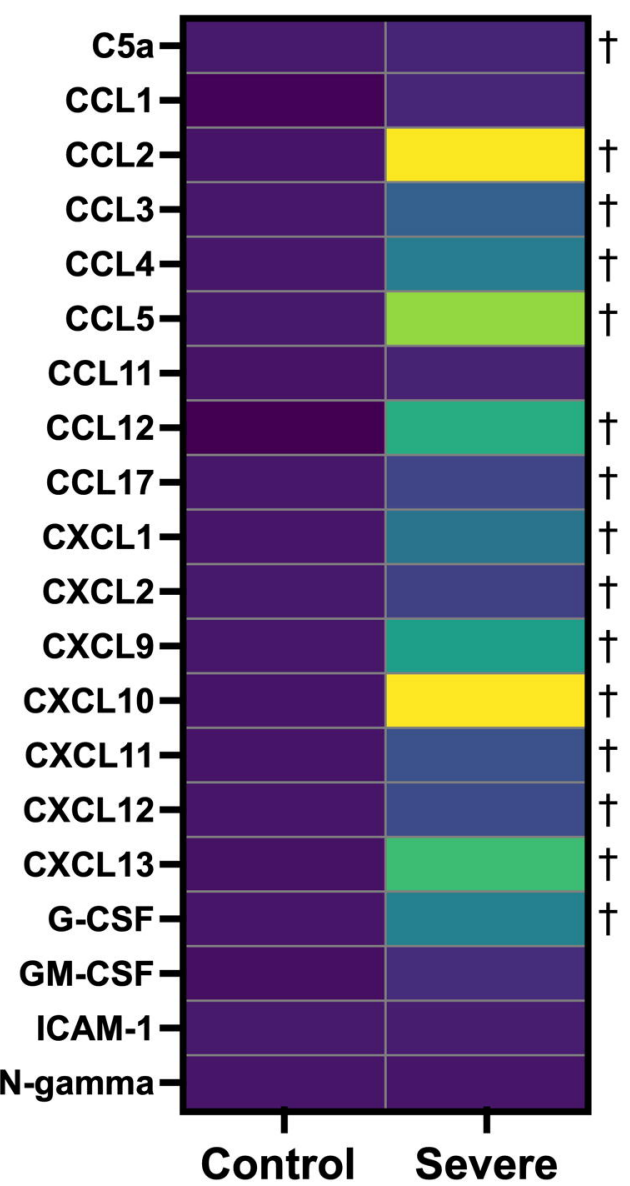

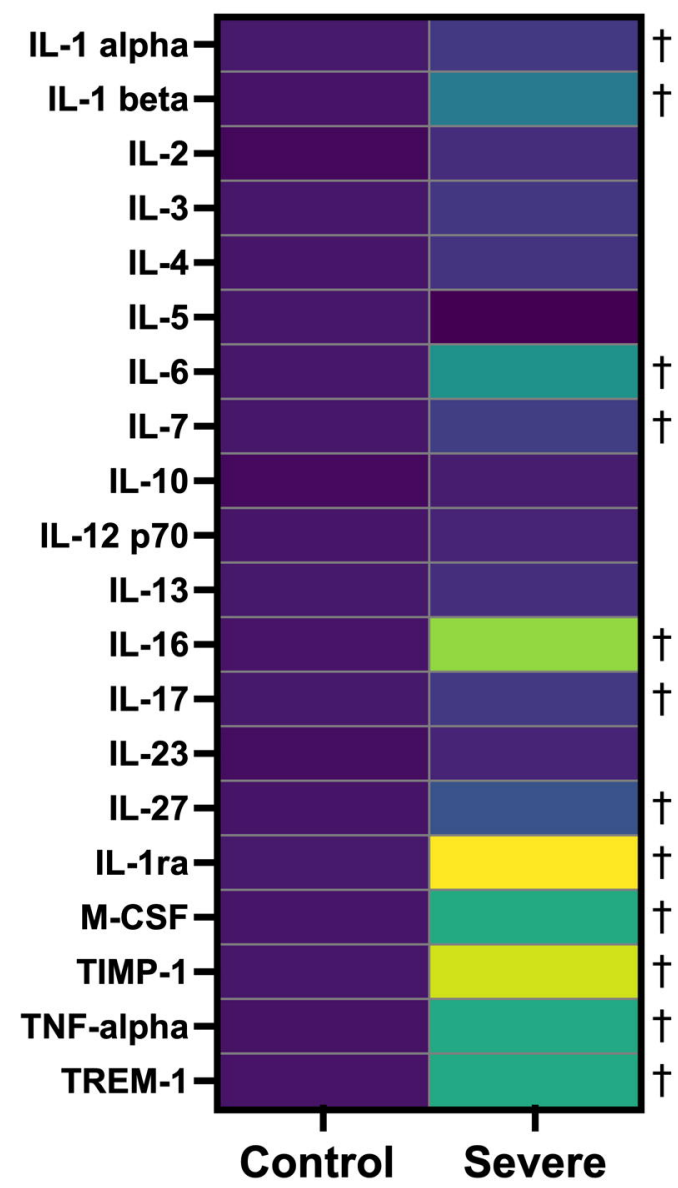

1.5

1.0

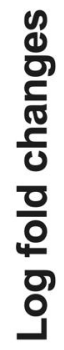

0.5

0 


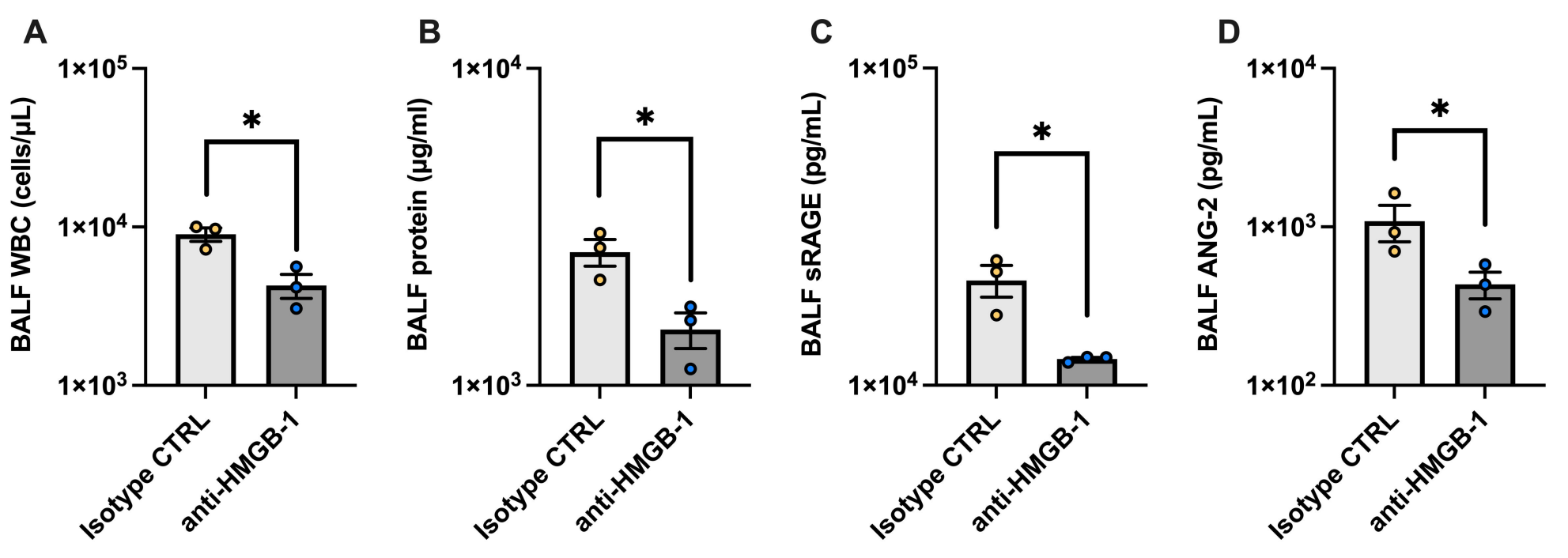

